Dieter Glebe, PhD, Series Editor

\title{
Hepatitis B virus-induced oncogenesis
}

\author{
Joachim Lupberger, Eberhard Hildt
}

Joachim Lupberger, Eberhard Hildt, University of Freiburg, Department of Internal Medicine II, Hugstetter Str. 55, D-79106 Freiburg, Germany

Correspondence to: Eberhard Hildt, University of Freiburg, Department of Internal Medicine II, Hugstetter Str. 55, Freiburg D-79106, Germany. eberhard.hildt@uniklinik-freiburg.de

Telephone: +49-761-2703510

Received: 2006-07-27 Accepted: 2006-09-28

\begin{abstract}
Hepatocellular carcinoma (HCC) is one of the most common cancers in the world with an annual incidence of more than 500000 in the year 2000. Its incidence is rising in many countries. Recently, it has been estimated that about $53 \%$ of $\mathrm{HCC}$ cases in the world are related to hepatitis $B$ virus (HBV). The epidemiological association of HBV with HCC is well established. In recent studies, it was revealed that HBsAg carriers have a 25-37 times increased risk of developing HCC as compared to non-infected people. At present, HBV-associated carcinogenesis can be seen as a multi-factorial process that includes both direct and indirect mechanisms that might act synergistically. The integration of HBV DNA into the host genome occurs at early steps of clonal tumor expansion. The integration has been shown in a number of cases to affect a variety of cancerrelated genes and to exert insertional mutagenesis. The permanent liver inflammation, induced by the immune response, resulting in a degeneration and regeneration process confers to the accumulation of critical mutations in the host genome. In addition to this, the regulatory proteins HBx and the PreS2 activators that can be encoded by the integrate exert a tumor promoter-like function resulting in positive selection of cells producing a functional regulatory protein. Gene expression profiling and proteomic techniques may help to characterize the molecular mechanisms driving HBV-associated carcinogenesis, and thus potentially identify new strategies in diagnosis and therapy.
\end{abstract}

(C) 2007 The WJG Press. All rights reserved.

Key words: Hepatitis B virus; Hepatocellular carcinoma; Regulatory proteins; Signal transduction

Lupberger J, Hildt E. Hepatitis B virus-induced oncogenesis. World J Gastroenterol 2007; 13(1): 74-81 http://www.wjgnet.com/1007-9327/13/74.asp

\section{INTRODUCTION}

With an estimate of more than 500000 incidences in the year 2000 hepatocellular carcinoma (HCC) is one of the most frequent malignant tumors worldwide and its incidence is rising in many countries ${ }^{[1-4]}$. Despite being the $5^{\text {th }}$ most frequent cancer in the world, HCC is the third leading cause of cancer death behind lung and stomach cancer. The high mortality associated with HCC is due to its unresponsiveness to treatment in many cases and symptoms of HCC often are recognized lately ${ }^{[5]}$. When viewed as estimated age-adjusted incidence rates of liver cancer per 100000 men, the figures ranged as follows: in Asia, from 35.5 in Eastern Asia, 18.3 in South-eastern Asia to 5.6 in Western Asia; in Africa, from 24.2 in Middle Africa, 14.4 in Eastern Africa, 13.5 in Western Africa, 6.2 in Southern Africa to 4.9 in Northern Africa; in Europe, from 9.8 in Southern Europe, 5.8 in Eastern and Western Europe to 2.6 in Northern Europe; and to values of 4.8 in South America; 4.1 in North America; 3.6 in Australia/ New Zealand and, finally, 2.1 in central America. In all regions, the rates recorded were two to three times higher in men than in women.

These significant differences in the geographic distribution of HCC incidence have led to identify chronic $\mathrm{HBV}$ infection as a leading risk factor for $\mathrm{HCC}^{[6-9]}$. Recently, it has been estimated that about $53 \%$ of HCC cases in the world are related to $\mathrm{HBV}^{[3]}$. The lifetime risk to develop a HCC was found to be increased even in patients that have cleared hepatitis B virus surface antigen (HBsAg) or with an occult HBV infection. Further risk factors include chronic HCV infection, exposure to aflatoxin $\mathrm{B}_{1}$, alcohol abuse, obesity and diabetes. Aflatoxin $\mathrm{B}_{1}\left(\mathrm{AFB}_{1}\right)$ is a fungal metabolite that contaminates the food supply in certain areas of the world. It is produced by Aspergillus flavus and related fungi that grow on improperly stored foods, such as corn, rice and peanuts. $\mathrm{AFB}_{1}$ requires metabolic conversion to its exo-8,9-epoxide in order to damage DNA. Coexistence of these risk factors, such as HBV and HCV infection or HBV infection and aflatoxin $\mathrm{B}_{1}$, increases the relative risk of HCC development ${ }^{[11-13]}$. While a variety of risk factors have been identified in the last years, here a short review describing the current state of knowledge of the molecular pathogenesis of $\mathrm{HBV}$-associated HCC 
is given. A focus of this review will be on the role of the $\mathrm{HBV}$-regulatory proteins in this process.

\section{EPIDEMIOLOGY OF HBV-ASSOCIATED HCC}

The epidemiological association of HBV with HCC is well established. In recent studies, it was revealed that HBsAg carriers have 25-37 times increased risk of developing HCC as compared to non-infected people ${ }^{[14,15]}$. Moreover, it was analyzed in more detail whether the viral status of the patients are correlated with the risk of developing HCC. HBV has been designated eight genotypes (A-H) based on genetic divergence. Each genotype has a distinct geographical and ethnic distribution. While genotypes $\mathrm{B}$ and $\mathrm{C}$ are prevalent in Asia, genotypes A and D occur frequently in Africa, Europe and India. There are conflicting data about the influence of HBV genotypes on HCC development ${ }^{[16-18]}$. Recent studies from Taiwan provide profound evidence for hepatitis $B$ virus e antigen ( $\mathrm{HBeAg}$ )-positive patients that $\mathrm{HBV}$ genotype $\mathrm{C}$ causes a more aggressive disease course as compared to genotype $\mathrm{B}^{[19-21]}$. On the other hand, there are reports from Taiwan describing that more than $50 \%$ of the HBV-related HCC patients are infected with genotype B. A study on Taiwanese pediatric patients with chronic HBV infection, who were followed for 15 years, showed that genotype B was identified in $74 \%$ of the children with HBV-associated $\mathrm{HCC}^{[22]}$. A further interesting observation is the prevalence of the T1762/A1764 mutation in the basal core promoter region which increases with the progression of liver disease. Since this mutation seems to be associated with HCC development, it might represent a helpful prognostic biomarker ${ }^{[2,34,24]}$.

The risk of HCC seems to be elevated with increasing HBV viral load ${ }^{[25]}$. Therefore, it is important to consider that most epidemiological analyses were based only on $\mathrm{HBs} A g$ positivity. A recent study revealed that the relative risk of HCC was increased by 6 -fold among patients who were positive for both $\mathrm{HBsAg}$ and $\mathrm{HBeAg}$, compared to those who were positive for HBsAg alone ${ }^{[15]}$. Based on this, it can be concluded that $\mathrm{HBeAg}$ could be an additional useful marker for risk of developing HCC, since HBeAg reflects productive $\mathrm{HBV}$ replication.

\section{DIRECT EFFECTS TRIGGERED BY THE INTEGRATION OF HBV-DNA INTO THE HOST GENOME}

Integration is not essential for the viral replication but it allows persistence of the viral genome. Almost all of the HBV-associated HCCs harbor chromosomally integrated HBV DNA ${ }^{[26-28]}$. In many cases, these integrated viral genomes are characterized by rearrangements and/or partial deletions. HBV integration can induce deletions in the host chromosome at the integration site ${ }^{[29]}$. Based on these observations, it was tempting to speculate that the integration event per se causes a deregulation of key regulators of cell cycle control. This cis-hypothesis (place of integration $=$ place of function) seems to be supported by the woodchuck hepatitis B virus (WHV)related HCC. Here, insertions of WHV-DNA into the c-myc or, preferentially the $\mathrm{N}$-myc2 gene, have been frequently detected ${ }^{[30-34]}$. However, in case of the HBVassociated HCC, site-specific integration of the HBV genome or integration of the HBV genome into known oncogenes seems to be a rare event. Interesting examples are the integration of HBV DNA in a cyclin A gene $e^{[35]}$, in the retinoic acid receptor beta gene, in the mevalonate kinase gene or in the sarco/endoplasmic reticulum calcium ATPase1 gene ${ }^{[28,36]}$.

It was recently confirmed, using a PCR-based approach, that HBV insertion into cellular genes is a frequent event that occurs early during $\mathrm{HBV}$ infection even after acute self-limiting hepatitis ${ }^{\left[{ }^{[3]}\right.}$ and that integration can occur in genes regulating cellular signal transduction cascades, proliferation control and cell viability. Recently, hTERT (human telomerase reverse transcriptase) that is part of the telomerase ribonuclear protein complex was found to be targeted in different HBV-associated HCCs ${ }^{[28,38,39]}$.

In light of these recent data, it will be an important issue to reconsider the role of the integration process for HBV-associated carcinogenesis. A helpful tool will be combining the analysis of putative HBV-specific integration sites with functional genomics of HBVassociated $\mathrm{HCCs}^{[40]}$.

\section{INDIRECT EFFECTS OF INTEGRATED HBV- DNA: HBX AND THE PRES2 ACTIVATOR}

\section{FAMILY}

\section{$H B x$}

In most integrated subviral HBV genomes, the open reading frame for $\mathrm{HBx}$ or PreS2 regulatory protein is conserved and can be transcribed ${ }^{[41]}$. The HBx gene is conserved among all mammalian hepadnaviruses. $\mathrm{HBx}$ is a small polypeptide $(17 \mathrm{kDa})$ that is produced at very low levels during chronic and acute hepatitis. Recently, a HBxlike regulatory protein was identified for duck hepatitis $\mathrm{B}$ virus $(\mathrm{DHBV})^{[42]}$. Since the time when HBx initially was described to act as a transcriptional activator ${ }^{[43,44]}$, a variety of functions have been ascribed to the still enigmatic $\mathrm{HBx}^{[45,46]}$. While the $\mathrm{X}$ protein is essential for viral replication in case of $\mathrm{WHV}^{[47]}$, there are conflicting results about the relevance of HBx for the viral life cycle in case of HBV. There are reports describing that expression of the viral genome occurs independently from $\mathrm{HBx}$ functionality ${ }^{[48-50]}$; other papers describe a relevance of $\mathrm{HBx}$ for HBV replication ${ }^{[51]}$. In transgenic mouse models harboring an overgenomic HBV integrate, it could be observed that HBV replication does not depend on the presence of a functional $\mathrm{HBx}^{[52]}$. Comparable results were obtained in cell culture models based on huh- 7 cells $^{[48,50]}$ while in case of HepG2 cells a reduction in HBx-deficient HBV genomes could be observed ${ }^{[5,54]}$. Moreover, infection experiments of primary tupaia hepatocytes revealed that HBx-deficient HBV particles are infectious (J. Köck, personal communication). 
HBx activates a broad variety of different promoter elements. Based on the pleiotropic nature of the $\mathrm{HBx}-$ dependent transcriptional regulation, it was concluded that $\mathrm{HBx}$ interferes with signaling cascades upstream from the transcription complex. These signaling cascades trigger activation of transcription factors like AP-1 (activator protein-1), NF- $\mathrm{B}$ (nuclear factor kappa B), SP1, and oct- $1^{[46,55]}$. HBx affects the expression of a variety of genes that are involved in the control of the cell cycle, proliferation or apoptosis. From the beginning, HBx was considered as a crucial viral protein for the process of HBV-associated carcinogenesis ${ }^{[45,56-58]}$ and this might have affected the focus of $\mathrm{HBx}$ research. In light of the putative role of $\mathrm{HBx}$ for viral carcinogenesis, the major focus of many research projects has been and is the interference of $\mathrm{HBx}$ with signal transduction cascades that affect the control of the cell cycle, proliferation or apoptosis. However, one should consider that selective over-expression of $\mathrm{HBx}$ reflects a situation that is different from the situation in an infected cell expressing the complete HBV genome. For example, it is well established that HBx is able to promote cellular proliferation ${ }^{[59]}$. On the other hand, it was shown that expression of the complete HBV genome that harbors the HBx and the PreS2 regulatory protein inhibits cell cycle progression ${ }^{[00]}$ (Figure 1).

The analysis of $\mathrm{HBx} /$ protein kinase $\mathrm{C}$ (PKC) interaction is such an example for many reports analyzing the interference of $\mathrm{HBx}$ with signaling cascades and correlating this with a putative role of $\mathrm{HBx}$ for HBVassociated carcinogenesis. There are conflicting reports about the interference of $\mathrm{HBx}$ with PKC signaling. On the one hand, there are reports describing an $\mathrm{HBx}$-dependent activation of PKC, mediated by an elevated DAG level in HBx-producing cells. In these studies, PKC is considered as an essential factor for the HBx-dependent activation of NF-kB or AP- $1^{[61,62]}$. Other reports provide evidence that $\mathrm{HBx}$ neither affects activity of PKC nor that PKC is essential for HBx-dependent transcriptional activation ${ }^{[63-65]}$. The interesting aspect of an $\mathrm{HBx}$-dependent activation of PKC is that a conclusive model for the role of HBx in the process of HBV-dependent carcinogenesis can be deduced. According to the two-step model of carcinogenesis ${ }^{[6]]}$ (initiation and promotion), the HBx-dependent activation of PKC could exert a tumor promoter-like function ${ }^{[61]}$. Independent from the point whether or not the $\mathrm{HBx}$ dependent activation of PKC exerts a tumor promoter-like function, there is profound experimental evidence from experiments with transgenic mice that $\mathrm{HBx}$ indeed could exert a tumor promoter-like function. Irradiation of $\mathrm{HBx}$ transgenics or exposure of these transgenics to mutagens (diethylnitrosamine) caused a significant increase in the amount of pre-neoplastic lesions as compared to the wildtype control animals ${ }^{[6,68]}$. Apart from this, a variety of HBx transgenic mouse models were established, but only in one model system so far direct formation of liver cancer could be observed ${ }^{[69]}$.

A tumor promoter-like function of $\mathrm{HBx}$ does not necessarily require an activation of PKC. Other pathways as the activation of c-Raf-1-MEK/MAP2 (mitogenactivated protein kinase 2) kinase cascade could fulfill

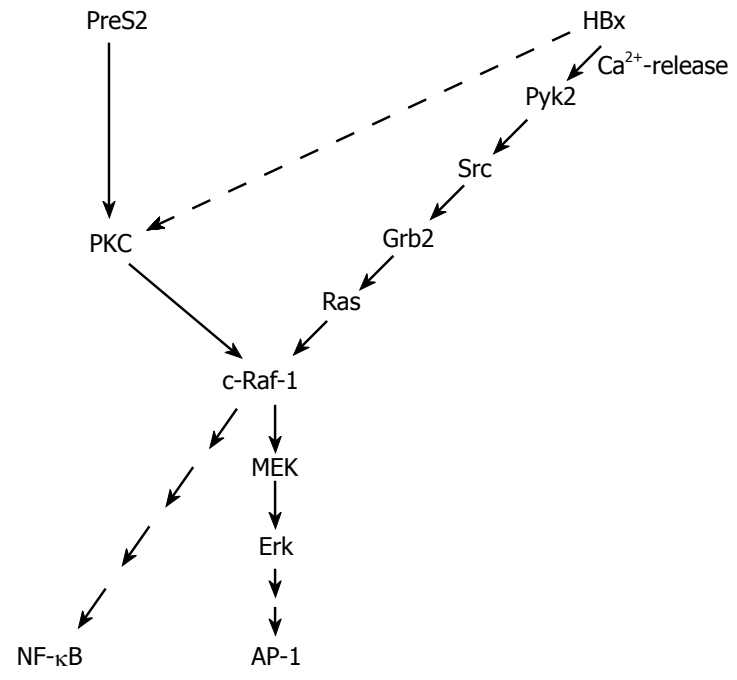

Figure 1 Major signaling pathways activated by the regulatory proteins $\mathrm{HBx}$ and Pres2 of HBV.

this function as well. Starting with the finding that $\mathrm{HBx}$ increases the Ras/GTP complex formation and thereby activates the c-Raf- 1 signal transduction cascade ${ }^{[70]}$, more and more data were collected elucidating the interference of $\mathrm{HBx}$ with signaling cascades upstream of Ras. One of the next steps was the observation that Src is activated in HBx-producing cells ${ }^{[71,72]}$, followed by the observation that $\mathrm{HBx}$ is able to activate the cytosolic $\mathrm{Ca}^{2+}$ dependent praline-rich tyrosine kinase $2(\mathrm{Pyk})^{[54]}$. Pyk is able to activate Src. A recent report describes an HBxdependent activation of FAK (focal adhesion kinase), a well known regulator of Src kinases ${ }^{[53]}$. The activation of these signaling cascades requires the presence of $\mathrm{HBx}$ in an extranuclear compartment. On the other hand, there is evidence that a fraction of $\mathrm{HBx}$ is localized within the nucleus. The subcellular distribution of $\mathrm{HBx}$ is still a matter of debate. There are reports providing evidence that HBx is localized in the cytoplasm as well as in the nucleus ${ }^{[49,73]}$. The different localizations are associated with different functions. HBx localized in the cytoplasm is able to modulate intracellular signal transduction cascades as described above. Moreover, an association of $\mathrm{HBx}$ with the outer membrane of mitochondria that induces oxidative stress was described ${ }^{[74-76]}$. HBx localized in the nucleus is suggested to interfere directly with transcription factors or to exert a transcription factor-like function. A direct interaction with CREB (cAMP responsive elementbinding protein) and ATF-2 (activating transcription factor 2) resulting in their increased DNA binding affinity ${ }^{[77]}$ was reported as well as an interaction with RNA polymerase II in the transcription complex ${ }^{[78,79]}$.

In addition to the interaction of $\mathrm{HBx}$ with the transcription machinery, there is evidence that $\mathrm{HBx}$ interferes at multiple steps with DNA repair and so confers to an increase of critical mutations. HBx was found to bind to DDB1 $1^{[80,81]}$, a subunit of the damaged DNA binding protein that is bound to damaged DNA, the first step in nucleotide excision repair. In cell culture experiments indeed the expression of $\mathrm{HBx}$ significantly inhibited the ability of cells to repair damaged DNA. 
Therefore, it was tempting to speculate that $\mathrm{HBx}$ could confer by this to an increase in the amount of critical mutations in the host genome ${ }^{[80]}$. However, analysis of mutation frequency in $\mathrm{HBx}$ transgenic mice did not corroborate this hypothesis ${ }^{[82]}$. Other reports focus on the interaction of $\mathrm{HBx}$ with $\mathrm{p} 53$. On the one hand, it has been shown an indirect inhibition of p53 by HBx: HBx causes a transcriptional repression of the human p53 gene ${ }^{[83]}$. On the other hand, there is evidence for the capacity of $\mathrm{HBx}$ to bind to $\mathrm{p} 53^{[84,85]}$. However, if the intracellular amounts of HBx and p53 are considered, there exists a tremendous excess of p53 as compared to $\mathrm{HBx}$ in the hepatocytes. The physiological significance of the direct p53/HBx interaction remains questionable.

\section{The family of the PreS2 activators}

Apart from the HBx-regulatory protein, the HBV genome encodes a second family of regulatory proteins: the PreS2 activators. Based on a subcloned HBV integrate of the human hepatoma cell line huH $4^{[86]}$ and of an integrate isolated from an $\mathrm{HBV}$-associated $\mathrm{HCC}^{[87]}$, preS/S genes that were truncated at the $3^{\prime}$ end were identified ${ }^{[41]}$. These $\mathrm{preS} / \mathrm{S}^{\mathrm{t}}$ genes encoded for C-terminally truncated surface proteins $\left(\mathrm{MHBs}^{\mathrm{t}}\right)$ that display a regulatory protein function. Initial analysis revealed that generation of the regulatory protein function requires at least deletion of the last transmembrane region in the S-domain (transmembrane region 3$)^{[88-91]}$. This results in $\mathrm{C}$-terminally truncated MHBs molecules that are endoplasmic reticulum (ER)membrane associated by the remaining transmembrane regions I and II of the $\mathrm{S}$ domain ${ }^{[02,93]}$. A prototype of the ER-membrane-associated $\mathrm{MHBs}^{\mathrm{t}}$ activator is encoded by the integrate isolated from the human hepatoma cell line huH $4^{[86]}$. This integrate is truncated at ntHBV 221 of the HBV genome resulting in a C-terminally truncated MHBs protein at amino acid (aa) $76\left(\mathrm{MHBs}^{\mathrm{t} 7 \mathrm{~g}}\right)$. A detailed analysis revealed that a variety of differences exist between the structural protein MHBs and its C-terminally truncated variant $\mathrm{MHBs}^{\mathrm{t}}$. In contrast to the structural protein $\mathrm{MHBs}$ and the regulatory variants, $\mathrm{MHBs}^{\mathrm{t}}$ are not secreted and lack the glycosylation at asparagine (asn) 4 of the PreS2 domain ${ }^{[2]}$. The intracellular retention of ER-membraneassociated $\mathrm{MHBs}^{\mathrm{t}}$ proteins gave raise to the hypothesis that the observed activator function is due to ER stress, induced by intracellular retention and subsequent accumulation in the $\mathrm{ER}^{[93-96]}$. More detailed analysis revealed, however, that the structural protein MHBs and the regulatory protein $\mathrm{MHBs}^{\mathrm{t}}$ differ in the topology of the PreS2 domain ${ }^{[97]}$. In case of the structural protein, the PreS2 domain faces the lumen of the endoplasmic reticulum and in accordance with this glycosylation at asn 4 can occur. In case of the activator protein $\mathrm{MHBs}^{\mathrm{t}}$, the PreS2 domain directs into the cytoplasm. This explains the lack of N-glycosylation at asn 4. The PreS2 domain facing the cytoplasm interacts with cytosolic binding partners, thereby triggering intracellular signal transduction cascades. In accordance with this, a minimal PreS2 activator was identified lacking any membrane insertion domain $\left(\mathrm{MHBs}^{\mathrm{t55}}\right)^{[88,67,98]}$. This minimal activator encompasses the complete PreS2 domain and is localized within the cytoplasm. Since the
PreS2 domain is sufficient to exert the regulatory protein function, this class of regulatory proteins was designated PreS2 activator. The family of PreS2- regulatory proteins encompasses the membrane-associated regulatory proteins, such as $\mathrm{MHBs}^{\mathrm{t} 76}$ or $\mathrm{MHBs}^{\mathrm{t} 167}$, and the non-membraneassociated short proteins, such as PreS2 domain $\left(\mathrm{MHBs}^{\mathrm{t55}}\right)$. There is no functional difference between the ER and the cytoplasmatically localized Pres 2 activators clearly arguing against the ER-overload hypothesis ${ }^{[97]}$.

The PreS1-PreS2 domain of the large hepatitis B virus surface protein (LHBs) displays a dual membrane topology ${ }^{[99-101]}$. In one fraction of LHBs, the first transmembrane region that is located at the beginning of the S-domain (aa 8-21) is used: in this case, the PreS1-PreS2 domain of LHBs faces the lumen of the endoplasmic reticulum. In case of the other fraction, this transmembrane region is not used, resulting in a PreS1PreS2 domain that directs into the cytoplasm. As described above, the cytoplasmic orientation of the PreS2 domain in case of the $\mathrm{MHBs}^{\mathrm{t}}$ proteins is causative for their regulatory protein function. In accordance with this, LHBs displays a regulatory protein function ${ }^{[102]}$ and belongs to the family of PreS2 activator proteins.

The PreS2 activators bind PKC- $\alpha$ in the cytoplasm. This interaction with PKC results in a DAG $(1,2$, sn diacylglycerol)-independent activation of PKC and phosphorylation of the PreS2 domain. The activation of PKC is transduced by the c-Raf-1/MEK/ERK (extracellular signal-regulated kinase) signal transduction cascade $^{[63]}$. This signal transduction cascade can exert a tumor promoter-like function according to the classical two-step model of carcinogenesis ${ }^{[66]}$. Indeed, transgenic mice expressing the PreS2 activator $\mathrm{MHBs}^{\mathrm{t}}{ }^{6}$ develop liver tumors at an age above $10 \mathrm{mo}$. Although the $\mathrm{MHBs}^{\mathrm{t} 76}$ protein is produced in very small but clearly detectable amounts in the $\mathrm{MHBs}^{\mathrm{t} 76}$ transgenic mice, a permanent activation of the Raf-1/MEK/ERK signal transduction cascade can be observed, resulting in an increased proliferation rate of the hepatocytes. The fact that $\mathrm{MHBs}^{\mathrm{t} 76}$ is produced in very small amounts ensures that the observed effects are not due to any overload-associated effects. The tumor formation in these mice can be explained by the permanent activation signal transduction cascades that exert a tumor promoter-like function ${ }^{[63]}$. Since tumor formation is observed in older animals, it can be assumed that during the aging process critical mutations are accumulated (initiation) and then the tumor promoter function positively selects these cells.

In case of the LHBs-transgenics, tumor formation can be observed as well ${ }^{[103]}$. In these mice, a very strong overproduction of the LHBs protein occurs, resulting in an intracellular accumulation of the protein and subsequent formation of ground glass hepatocytes. This permanent accumulation results in a situation comparable to a storage disease. Tumor formation in these transgenics was explained by the resulting permanent inflammation ${ }^{[103-105]}$. In light of the observation that LHBs can act as a regulatory protein, however, the regulatory protein function that is immanent to LHBs should be considered as an additional factor conferring to tumor formation in these mice. The overload-associated stress 
and inflammation results in the formation of critical mutations (initiation) and the permanent activation of the $\mathrm{PKC} / \mathrm{Raf} / \mathrm{MEK} / \mathrm{ERK}$ signal transduction cascade which exerts a tumor promoter-like function.

\section{Immune pathogenesis of HCC}

A major factor in the process of $\mathrm{HBV}$-associated HCC development is the immune system ${ }^{[104,106,107]}$. The relevance of a chronic, virus-specific immune response for development of HBV-associated carcinoma was shown in an elegant experiment from F. Chisari`s laboratory ${ }^{[108]}$. Transgenic mice that produce non-cytopathic amounts of $\mathrm{HBsAg}$ were used. In these mice, immunologic tolerance against the transgene product can be observed. In accordance with this, no evidence of the liver disease was observed. These mice were subjected to thymectomy and lethally irradiated. One group was reconstituted with the bone marrow and spleen cells derived from non-transgenic littermates that were vaccinated with a recombinant $\mathrm{HBsAg}$ encoding vaccinia virus resulting in $\mathrm{HBsAg-}$ specific cytotoxic T lymphocytes (CTLs) and antibodies. The other group was reconstituted with the bone marrow and spleen cells derived from transgenic donors that were immunologically tolerant.

In this animal model, the development of hepatitis and later of chronic hepatitis and finally HCC development could be exclusively observed in the mice that were reconstituted with the bone marrow and spleen cells derived from the vaccinated non-transgenic animals, but not in the control groups. Based on this, it was concluded that the immune system-mediated chronic inflammation of the liver, continuous cell death and subsequent cell proliferation might increase the frequency of genetic alterations and the risk of cancer ${ }^{[104,109-111]}$. This scenario is not exclusively restricted to HBV. Chronic inflammation, degeneration and regeneration are common to a variety of human liver diseases, such as glycogen storage disease or alcoholism or HCV infection, that can finally result in liver carcinoma development ${ }^{[5]}$. This means that an ineffective immune response can be the principal oncogenic factor during a chronic HBV infection in man. In other words, the same T-cell response can have complete different effects: if the $\mathrm{T}$ cell response is strong enough, HBV can be eliminated from the liver, if not, a pro-carcinogenic effect can be induced by permanently triggering necroinflammatory disease without resulting in a final eradication of HBV from the liver. An interesting aspect is that the nucleoside analogue on lamivudine in patients with chronic hepatitis B can induce the recovery of antiviral $T$ cell responses. However, restoration of HBV-specific $\mathrm{T}$ cell reactivity is only transient. The transient nature of the immune reconstitution may represent a favorable condition for virus reactivation once lamivudine therapy is withdrawn.

\section{CONCLUSION}

At present, HBV-associated carcinogenesis can be seen as a multi-factorial process that includes both direct and indirect mechanisms that might act synergistically.
The integration of HBV DNA into the host genome occurs at early steps of clonal tumor expansion. The integration has been shown in a number of cases to affect a variety of cancer-related genes and to exert insertional mutagenesis. The permanent liver inflammation resulting in a degeneration and regeneration process confers to the accumulation of critical mutations in the host genome. In addition, the regulatory proteins $\mathrm{HBx}$ and the PreS2 activators that can be encoded by the integrate can exert a tumor promoter-like function, resulting in positive selection of cells producing a functional regulatory protein.

Based on new technologies, including gene expression profiling and proteomics, it should be possible to further reveal the molecular mechanisms underlying $\mathrm{HBV}$ associated HCC development and to identify novel diagnostic markers as well as therapeutic and preventive targets.

\section{REFERENCES}

1 El-Serag HB. Hepatocellular carcinoma: recent trends in the United States. Gastroenterology 2004; 127: S27-S34

2 Llovet JM, Burroughs A, Bruix J. Hepatocellular carcinoma. Lancet 2003; 362: 1907-1917

3 Parkin DM, Bray FI, Devesa SS. Cancer burden in the year 2000. The global picture. Eur J Cancer 2001; 37 Suppl 8: S4-S66

4 Shibuya K, Mathers CD, Boschi-Pinto C, Lopez AD, Murray CJ. Global and regional estimates of cancer mortality and incidence by site: II. Results for the global burden of disease 2000. BMC Cancer 2002; 2: 37

5 Blum HE. Hepatocellular carcinoma: therapy and prevention. World J Gastroenterol 2005; 11: 7391-7400

6 Ahn SH, Park YN, Park JY, Chang HY, Lee JM, Shin JE, Han KH, Park C, Moon YM, Chon CY. Long-term clinical and histological outcomes in patients with spontaneous hepatitis $\mathrm{B}$ surface antigen seroclearance. J Hepatol 2005; 42: 188-194

7 Evans AA, O'Connell AP, Pugh JC, Mason WS, Shen FM, Chen GC, Lin WY, Dia A, M'Boup S, Dramé B, London WT. Geographic variation in viral load among hepatitis B carriers with differing risks of hepatocellular carcinoma. Cancer Epidemiol Biomarkers Prev 1998; 7: 559-565

8 Montalto G, Cervello M, Giannitrapani L, Dantona F, Terranova A, Castagnetta LA. Epidemiology, risk factors, and natural history of hepatocellular carcinoma. Ann N Y Acad Sci 2002; 963: 13-20

9 Pollicino T, Squadrito G, Cerenzia G, Cacciola I, Raffa G, Craxi A, Farinati F, Missale G, Smedile A, Tiribelli C, Villa E, Raimondo G. Hepatitis B virus maintains its pro-oncogenic properties in the case of occult HBV infection. Gastroenterology 2004; 126: 102-110

10 Block TM, Mehta AS, Fimmel CJ, Jordan R. Molecular viral oncology of hepatocellular carcinoma. Oncogene 2003; 22 5093-5107

11 Kew MC. Synergistic interaction between aflatoxin B1 and hepatitis B virus in hepatocarcinogenesis. Liver Int 2003; 23: 405-409

12 Olivier M, Hussain SP, Caron de Fromentel C, Hainaut P, Harris CC. TP53 mutation spectra and load: a tool for generating hypotheses on the etiology of cancer. IARC Sci Publ 2004; (157): 247-270

13 Velázquez RF, Rodríguez M, Navascués CA, Linares A, Pérez R, Sotorríos NG, Martínez I, Rodrigo L. Prospective analysis of risk factors for hepatocellular carcinoma in patients with liver cirrhosis. Hepatology 2003; 37: 520-527

14 Hassan MM, Hwang LY, Hatten CJ, Swaim M, Li D, Abbruzzese JL, Beasley P, Patt YZ. Risk factors for hepatocellular carcinoma: synergism of alcohol with viral hepatitis and diabetes mellitus. Hepatology 2002; 36: 1206-1213 
15 Yang HI, Lu SN, Liaw YF, You SL, Sun CA, Wang LY, Hsiao CK, Chen PJ, Chen DS, Chen CJ. Hepatitis B e antigen and the risk of hepatocellular carcinoma. N Engl J Med 2002; 347: 168-174

16 Kao JH. Hepatitis B viral genotypes: clinical relevance and molecular characteristics. J Gastroenterol Hepatol 2002; 17: 643-650

17 Orito E, Mizokami M. Hepatitis B virus genotypes and hepatocellular carcinoma in Japan. Intervirology 2003; 46: 408-412

18 Sugauchi F, Kumada H, Acharya SA, Shrestha SM, Gamutan MT, Khan M, Gish RG, Tanaka Y, Kato T, Orito E, Ueda R, Miyakawa Y, Mizokami M. Epidemiological and sequence differences between two subtypes (Ae and Aa) of hepatitis B virus genotype A. J Gen Virol 2004; 85: 811-820

19 Chen CH, Lee CM, Lu SN, Changchien CS, Eng HL, Huang $\mathrm{CM}$, Wang JH, Hung $\mathrm{CH}, \mathrm{Hu} \mathrm{TH}$. Clinical significance of hepatitis $\mathrm{B}$ virus (HBV) genotypes and precore and core promoter mutations affecting $\mathrm{HBV}$ e antigen expression in Taiwan. J Clin Microbiol 2005; 43: 6000-6006

20 Kao JH, Chen PJ, Lai MY, Chen DS. Hepatitis B virus genotypes and spontaneous hepatitis B e antigen seroconversion in Taiwanese hepatitis B carriers. I Med Virol 2004; 72: 363-369

21 Yu MW, Yeh SH, Chen PJ, Liaw YF, Lin CL, Liu CJ, Shih WL, Kao JH, Chen DS, Chen CJ. Hepatitis B virus genotype and DNA level and hepatocellular carcinoma: a prospective study in men. J Natl Cancer Inst 2005; 97: 265-272

22 Ni YH, Chang MH, Wang KJ, Hsu HY, Chen HL, Kao JH, Yeh SH, Jeng YM, Tsai KS, Chen DS. Clinical relevance of hepatitis $B$ virus genotype in children with chronic infection and hepatocellular carcinoma. Gastroenterology 2004; 127: 1733-1738

23 Kuang SY, Jackson PE, Wang JB, Lu PX, Muñoz A, Qian GS, Kensler TW, Groopman JD. Specific mutations of hepatitis B virus in plasma predict liver cancer development. Proc Natl Acad Sci USA 2004; 101: 3575-3580

24 Liu CJ, Chen BF, Chen PJ, Lai MY, Huang WL, Kao JH, Chen DS. Role of hepatitis B viral load and basal core promoter mutation in hepatocellular carcinoma in hepatitis B carriers. J Infect Dis 2006; 193: 1258-1265

25 Iloeje UH, Yang HI, Su J, Jen CL, You SL, Chen CJ. Predicting cirrhosis risk based on the level of circulating hepatitis B viral load. Gastroenterology 2006; 130: 678-686

26 Beasley RP, Hwang LY, Lin CC, Chien CS. Hepatocellular carcinoma and hepatitis B virus. A prospective study of 22707 men in Taiwan. Lancet 1981; 2: 1129-1133

27 Brechot C, Pourcel C, Louise A, Rain B, Tiollais P. Presence of integrated hepatitis B virus DNA sequences in cellular DNA of human hepatocellular carcinoma. Nature 1980; 286: 533-535

28 Paterlini-Bréchot $\mathbf{P}$, Saigo K, Murakami Y, Chami M, Gozuacik D, Mugnier C, Lagorce D, Bréchot C. Hepatitis B virus-related insertional mutagenesis occurs frequently in human liver cancers and recurrently targets human telomerase gene. Oncogene 2003; 22: 3911-3916

29 Thorgeirsson SS, Grisham JW. Molecular pathogenesis of human hepatocellular carcinoma. Nat Genet 2002; 31: 339-346

30 Bruni R, D'Ugo E, Villano U, Fourel G, Buendia MA, Rapicetta $M$. The win locus involved in activation of the distal N-myc2 gene upon WHV integration in woodchuck liver tumors harbors S/MAR elements. Virology 2004; 329: 1-10

31 Buendia MA. Hepatitis B viruses and cancerogenesis. Biomed Pharmacother 1998; 52: 34-43

32 Fourel G, Trepo C, Bougueleret L, Henglein B, Ponzetto A, Tiollais P, Buendia MA. Frequent activation of N-myc genes by hepadnavirus insertion in woodchuck liver tumours. $\mathrm{Na}$ ture 1990; 347: 294-298

33 Hsu T, Möröy T, Etiemble J, Louise A, Trépo C, Tiollais P, Buendia MA. Activation of c-myc by woodchuck hepatitis virus insertion in hepatocellular carcinoma. Cell 1988; 55: 627-635

34 Jacob JR, Sterczer A, Toshkov IA, Yeager AE, Korba BE, Cote PJ, Buendia MA, Gerin JL, Tennant BC. Integration of woodchuck hepatitis and $\mathrm{N}$-myc rearrangement determine size and histologic grade of hepatic tumors. Hepatology 2004 39: 1008-1016

35 Wang J, Chenivesse X, Henglein B, Bréchot C. Hepatitis $B$ virus integration in a cyclin A gene in a hepatocellular carcinoma. Nature 1990; 343: 555-557

36 Bréchot C, Gozuacik D, Murakami Y, Paterlini-Bréchot P. Molecular bases for the development of hepatitis B virus (HBV)-related hepatocellular carcinoma (HCC). Semin Cancer Biol 2000; 10: 211-231

37 Murakami Y, Saigo K, Takashima H, Minami M, Okanoue T, Bréchot C, Paterlini-Bréchot P. Large scaled analysis of hepatitis B virus (HBV) DNA integration in HBV related hepatocellular carcinomas. Gut 2005; 54: 1162-1168

38 Horikawa I, Barrett JC. cis-Activation of the human telomerase gene (hTERT) by the hepatitis B virus genome. J Natl Cancer Inst 2001; 93: 1171-1173

39 Hytiroglou $\mathbf{P}$, Theise ND. Telomerase activation in human hepatocarcinogenesis. Am J Gastroenterol 2006; 101: 839-841

40 Thorgeirsson SS, Lee JS, Grisham JW. Functional genomics of hepatocellular carcinoma. Hepatology 2006; 43: S145-S150

41 Schlüter V, Meyer M, Hofschneider PH, Koshy R, Caselmann WH. Integrated hepatitis $B$ virus $X$ and $3^{\prime}$ truncated preS/S sequences derived from human hepatomas encode functionally active transactivators. Oncogene 1994; 9: 3335-3344

42 Chang SF, Netter HJ, Hildt E, Schuster R, Schaefer S, Hsu YC, Rang A, Will H. Duck hepatitis B virus expresses a regulatory HBx-like protein from a hidden open reading frame. J Virol 2001; 75: 161-170

43 Twu JS, Schloemer RH. Transcriptional trans-activating function of hepatitis B virus. J Virol 1987; 61: 3448-3453

44 Wollersheim M, Debelka U, Hofschneider PH. A transactivating function encoded in the hepatitis B virus $\mathrm{X}$ gene is conserved in the integrated state. Oncogene 1988; 3: 545-552

45 Cougot D, Neuveut C, Buendia MA. HBV induced carcinogenesis. J Clin Virol 2005; 34 Suppl 1: S75-S78

46 Zhang X, Zhang H, Ye L. Effects of hepatitis B virus X protein on the development of liver cancer. I Lab Clin Med 2006; 147: 58-66

47 Zoulim F, Saputelli J, Seeger C. Woodchuck hepatitis virus X protein is required for viral infection in vivo. J Virol 1994; 68: 2026-2030

48 Blum HE, Zhang ZS, Galun E, von Weizsäcker F, Garner B, Liang TJ, Wands JR. Hepatitis B virus X protein is not central to the viral life cycle in vitro. J Virol 1992; 66: 1223-1227

49 Hafner A, Brandenburg B, Hildt E. Reconstitution of gene expression from a regulatory-protein-deficient hepatitis $B$ virus genome by cell-permeable HBx protein. EMBO Rep 2003; 4: 767-773

50 Stöckl L, Berting A, Malkowski B, Foerste R, Hofschneider $\mathrm{PH}$, Hildt E. Integrity of c-Raf-1/MEK signal transduction cascade is essential for hepatitis B virus gene expression. Oncogene 2003; 22: 2604-2610

51 Melegari M, Wolf SK, Schneider RJ. Hepatitis B virus DNA replication is coordinated by core protein serine phosphorylation and HBx expression. J Virol 2005; 79 9810-9820

52 Reifenberg K, Nusser P, Löhler J, Spindler G, Kuhn C, von Weizsäcker F, Köck J. Virus replication and virion export in X-deficient hepatitis B virus transgenic mice. J Gen Virol 2002; 83: $991-996$

53 Bouchard MJ, Wang L, Schneider RJ. Activation of focal adhesion kinase by hepatitis $\mathrm{B}$ virus $\mathrm{HBx}$ protein: multiple functions in viral replication. J Virol 2006; 80: 4406-4414

54 Bouchard MJ, Wang LH, Schneider RJ. Calcium signaling by HBx protein in hepatitis B virus DNA replication. Science 2001; 294: 2376-2378

55 Waris G, Siddiqui A. Regulatory mechanisms of viral hepatitis B and C. J Biosci 2003; 28: 311-321

56 Chan HL, Sung JJ. Hepatocellular carcinoma and hepatitis B virus. Semin Liver Dis 2006; 26: 153-161

57 Koike K, Tsutsumi T, Fujie H, Shintani Y, Kyoji M. Molecular mechanism of viral hepatocarcinogenesis. Oncology 2002; 62 
Suppl 1: 29-37

58 Staib F, Hussain SP, Hofseth LJ, Wang XW, Harris CC. TP53 and liver carcinogenesis. Hum Mutat 2003; 21: 201-216

59 Madden CR, Slagle BL. Stimulation of cellular proliferation by hepatitis B virus X protein. Dis Markers 2001; 17: 153-157

60 Friedrich B, Wollersheim M, Brandenburg B, Foerste R, Will $\mathrm{H}$, Hildt E. Induction of anti-proliferative mechanisms in hepatitis B virus producing cells. J Hepatol 2005; 43: 696-703

61 Kekulé AS, Lauer U, Weiss L, Luber B, Hofschneider PH. Hepatitis B virus transactivator HBx uses a tumour promoter signalling pathway. Nature 1993; 361: 742-745

62 Luber B, Lauer U, Weiss L, Höhne M, Hofschneider PH, Kekulé AS. The hepatitis B virus transactivator HBx causes elevation of diacylglycerol and activation of protein kinase $C$. Res Virol 1993; 144: 311-321

63 Hildt E, Munz B, Saher G, Reifenberg K, Hofschneider PH. The PreS2 activator MHBs(t) of hepatitis $B$ virus activates c-raf-1/Erk2 signaling in transgenic mice. $E M B O$ J 2002; 21: 525-535

64 Lucito R, Schneider RJ. Hepatitis B virus X protein activates transcription factor NF-kappa B without a requirement for protein kinase C. J Virol 1992; 66: 983-991

65 Murakami S, Cheong J, Ohno S, Matsushima K, Kaneko S. Transactivation of human hepatitis B virus $X$ protein, $H B x$, operates through a mechanism distinct from protein kinase C and okadaic acid activation pathways. Virology 1994; 199: 243-246

66 Boutwell RK. The function and mechanism of promoters of carcinogenesis. CRC Crit Rev Toxicol 1974; 2: 419-443

67 Madden CR, Finegold MJ, Slagle BL. Hepatitis B virus $X$ protein acts as a tumor promoter in development of diethylnitrosamine-induced preneoplastic lesions. J Virol 2001; 75: 3851-3858

68 Zhu H, Wang Y, Chen J, Cheng G, Xue J. Transgenic mice expressing hepatitis $\mathrm{B}$ virus $\mathrm{X}$ protein are more susceptible to carcinogen induced hepatocarcinogenesis. Exp Mol Pathol 2004; 76: 44-50

69 Kim CM, Koike K, Saito I, Miyamura T, Jay G. HBx gene of hepatitis $\mathrm{B}$ virus induces liver cancer in transgenic mice. Nature 1991; 351: 317-320

70 Benn J, Schneider RJ. Hepatitis B virus HBx protein activates Ras-GTP complex formation and establishes a Ras, Raf, MAP kinase signaling cascade. Proc Natl Acad Sci USA 1994; 91: 10350-10354

71 Klein NP, Bouchard MJ, Wang LH, Kobarg C, Schneider RJ. Src kinases involved in hepatitis B virus replication. $E M B O J$ 1999; 18: 5019-5027

72 Klein NP, Schneider RJ. Activation of Src family kinases by hepatitis B virus HBx protein and coupled signaling to Ras. Mol Cell Biol 1997; 17: 6427-6436

73 Sirma H, Weil R, Rosmorduc O, Urban S, Israël A, Kremsdorf $\mathrm{D}$, Bréchot C. Cytosol is the prime compartment of hepatitis $B$ virus $X$ protein where it colocalizes with the proteasome. Oncogene 1998; 16: 2051-2063

74 Huh KW, Siddiqui A. Characterization of the mitochondrial association of hepatitis B virus X protein, HBx. Mitochondrion 2002; 1: 349-359

75 Lee YI, Hwang JM, Im JH, Lee YI, Kim NS, Kim DG, Yu DY, Moon HB, Park SK. Human hepatitis B virus-X protein alters mitochondrial function and physiology in human liver cells. J Biol Chem 2004; 279: 15460-15471

76 Waris G, Huh KW, Siddiqui A. Mitochondrially associated hepatitis $\mathrm{B}$ virus $\mathrm{X}$ protein constitutively activates transcription factors STAT-3 and NF-kappa B via oxidative stress. Mol Cell Biol 2001; 21: 7721-7730

77 Maguire HF, Hoeffler JP, Siddiqui A. HBV X protein alters the DNA binding specificity of CREB and ATF-2 by proteinprotein interactions. Science 1991; 252: 842-844

78 Haviv I, Shamay M, Doitsh G, Shaul Y. Hepatitis B virus pX targets TFIIB in transcription coactivation. Mol Cell Biol 1998; 18: $1562-1569$

79 Haviv I, Vaizel D, Shaul Y. pX, the HBV-encoded coactivator, interacts with components of the transcription machinery and stimulates transcription in a TAF-independent manner. EMBO J 1996; 15: 3413-3420

80 Becker SA, Lee TH, Butel JS, Slagle BL. Hepatitis B virus $X$ protein interferes with cellular DNA repair. J Virol 1998; 72 266-272

81 Wentz MJ, Becker SA, Slagle BL. Dissociation of DDB1binding and transactivation properties of the hepatitis $B$ virus X protein. Virus Res 2000; 68: 87-92

82 Madden CR, Finegold MJ, Slagle BL. Expression of hepatitis B virus $X$ protein does not alter the accumulation of spontaneous mutations in transgenic mice. J Virol 2000; 74: 5266-5272

83 Lee SG, Rho HM. Transcriptional repression of the human p53 gene by hepatitis B viral X protein. Oncogene 2000; 19: 468-471

84 Elmore LW, Hancock AR, Chang SF, Wang XW, Chang S, Callahan CP, Geller DA, Will H, Harris CC. Hepatitis B virus $X$ protein and $\mathrm{p} 53$ tumor suppressor interactions in the modulation of apoptosis. Proc Natl Acad Sci USA 1997; 94: $14707-14712$

85 Ueda H, Ullrich SJ, Gangemi JD, Kappel CA, Ngo L, Feitelson MA, Jay G. Functional inactivation but not structural mutation of p53 causes liver cancer. Nat Genet 1995; 9: 41-47

86 Kekulé AS, Lauer U, Meyer M, Caselmann WH, Hofschneider $\mathrm{PH}$, Koshy R. The preS2/S region of integrated hepatitis B virus DNA encodes a transcriptional transactivator. Nature 1990; 343: 457-461

87 Caselmann WH, Meyer M, Kekulé AS, Lauer U, Hofschneider $\mathrm{PH}$, Koshy R. A trans-activator function is generated by integration of hepatitis B virus preS/S sequences in human hepatocellular carcinoma DNA. Proc Natl Acad Sci USA 1990; 87: 2970-2974

88 Lauer U, Weiss L, Hofschneider PH, Kekulé AS. The hepatitis $B$ virus pre- $S / S(t)$ transactivator is generated by $3^{\prime}$ truncations within a defined region of the S gene. J Virol 1992; 66: 5284-5289

89 Levrero M, Balsano C, Avantaggiati ML, Natoli G, Chirillo P, De Marzio E, Collepardo D, Costanzo A. Characterization of the hepatitis $B$ virus transactivators: a possible direct role of the virus in the development of hepatocellular carcinoma. J Surg Oncol Suppl 1993; 3: 34-36

90 Natoli G, Avantaggiati ML, Balsano C, De Marzio E, Collepardo D, Elfassi E, Levrero M. Characterization of the hepatitis B virus preS/S region encoded transcriptional transactivator. Virology 1992; 187: 663-670

91 Natoli G, Balsano C, Avantaggiati ML, De Marzio E, Artini M, Collepardo D, Elfassi E, Levrero M. Truncated pre-S/S proteins transactivate multiple target sequences. Arch Virol Suppl 1992; 4: 65-69

92 Hildt E, Urban S, Lauer U, Hofschneider PH, Kekulé AS. ER-localization and functional expression of the HBV transactivator MHBst. Oncogene 1993; 8: 3359-3367

93 Meyer M, Caselmann WH, Schlüter V, Schreck R, Hofschneider PH, Baeuerle PA. Hepatitis B virus transactivator MHBst: activation of NF-kappa B, selective inhibition by antioxidants and integral membrane localization. $E M B O J$ 1992; 11: 2991-3001

94 Caselmann WH, Renner M, Schlüter V, Hofschneider $\mathrm{PH}$ Koshy R, Meyer M. The hepatitis B virus MHBst167 protein is a pleiotropic transactivator mediating its effect via ubiquitous cellular transcription factors. J Gen Virol 1997; $78(\mathrm{Pt} 6)$ : 1487-1495

95 Jüngst C, Cheng B, Gehrke R, Schmitz V, Nischalke HD, Ramakers J, Schramel P, Schirmacher P, Sauerbruch T, Caselmann WH. Oxidative damage is increased in human liver tissue adjacent to hepatocellular carcinoma. Hepatology 2004; 39: 1663-1672

$96 \mathbf{X u ~ Z}$, Jensen G, Yen TS. Activation of hepatitis B virus S promoter by the viral large surface protein via induction of stress in the endoplasmic reticulum. J Virol 1997; 71: 7387-7392

97 Hildt E, Urban S, Hofschneider PH. Characterization of essential domains for the functionality of the MHBst transcriptional activator and identification of a minimal MHBst activator. Oncogene 1995; 11: 2055-2066

98 Hildt E, Urban S, Eckerskorn C, Hofschneider PH. Isolation 
of highly purified, functional carboxy-terminally truncated hepatitis B virus middle surface protein activators from eucaryotic expression systems. Hepatology 1996; 24: 502-507

99 Bruss V, Lu X, Thomssen R, Gerlich WH. Post-translational alterations in transmembrane topology of the hepatitis $B$ virus large envelope protein. EMBO J 1994; 13: 2273-2279

100 Ostapchuk P, Hearing P, Ganem D. A dramatic shift in the transmembrane topology of a viral envelope glycoprotein accompanies hepatitis B viral morphogenesis. EMBO J 1994; 13: $1048-1057$

101 Prange R, Streeck RE. Novel transmembrane topology of the hepatitis B virus envelope proteins. EMBO J 1995; 14: 247-256

102 Hildt E, Saher G, Bruss V, Hofschneider PH. The hepatitis B virus large surface protein (LHBs) is a transcriptional activator. Virology 1996; 225: 235-239

103 Chisari FV, Klopchin K, Moriyama T, Pasquinelli C, Dunsford HA, Sell S, Pinkert CA, Brinster RL, Palmiter RD. Molecular pathogenesis of hepatocellular carcinoma in hepatitis B virus transgenic mice. Cell 1989; 59: 1145-1156

104 Chisari FV. Rous-Whipple Award Lecture. Viruses, immunity, and cancer: lessons from hepatitis B. Am I Pathol 2000; 156:

\section{7-1132}

105 Dunsford HA, Sell S, Chisari FV. Hepatocarcinogenesis due to chronic liver cell injury in hepatitis B virus transgenic mice. Cancer Res 1990; 50: 3400-3407

106 Rehermann B. Immune responses in hepatitis B virus infection. Semin Liver Dis 2003; 23: 21-38

107 Rehermann B, Nascimbeni M. Immunology of hepatitis B virus and hepatitis $C$ virus infection. Nat Rev Immunol 2005; 5: 215-229

108 Nakamoto Y, Guidotti LG, Kuhlen CV, Fowler P, Chisari FV. Immune pathogenesis of hepatocellular carcinoma. J Exp Med 1998; 188: 341-350

109 Chisari FV, Pinkert CA, Milich DR, Filippi P, McLachlan A, Palmiter RD, Brinster RL. A transgenic mouse model of the chronic hepatitis B surface antigen carrier state. Science 1985; 230: $1157-1160$

110 Ferrari C, Missale G, Boni C, Urbani S. Immunopathogenesis of hepatitis B. J Hepatol 2003; 39 Suppl 1: S36-S42

111 Visvanathan K, Lewin SR. Immunopathogenesis: role of innate and adaptive immune responses. Semin Liver Dis 2006; 26: $104-115$

S- Editor Liu Y L- Editor Kumar M E- Editor Ma WH 